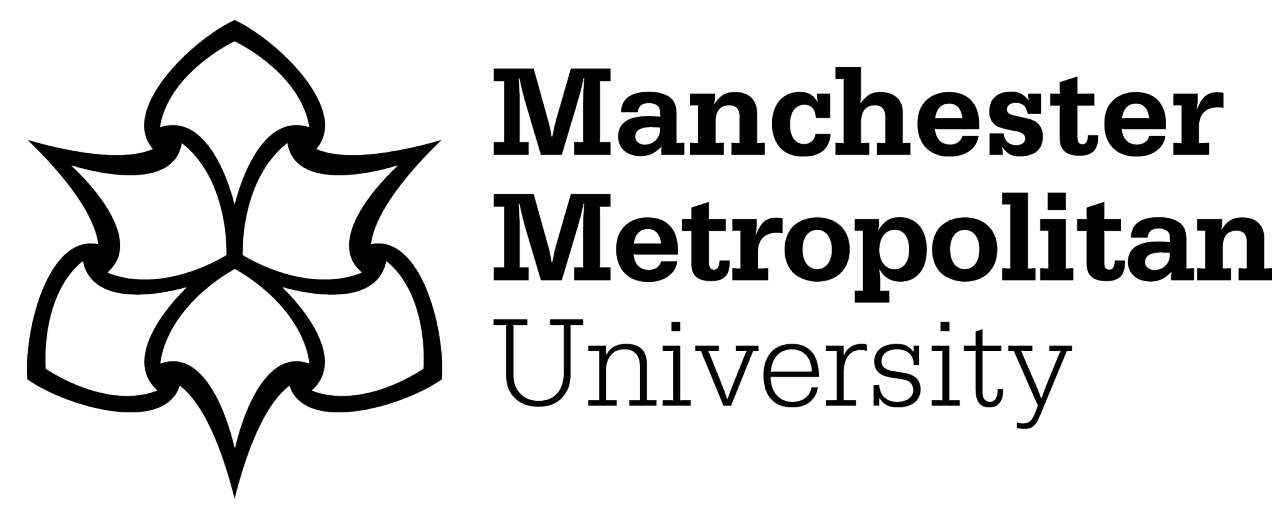

Han, SL, Henninger, CE, Apeagyei, P and Tyler, D (2017) Determining effective sustainable fashion communication strategies. In: Sustainability in fashion: a cradle to upcycle approach. Palgrave Macmillan, pp. 127-150. ISBN 9783319512525

Downloaded from: https://e-space.mmu.ac.uk/619007/

Publisher: Palgrave Macmillan

Please cite the published version 


\title{
Determining Effective Sustainable Fashion Communication Strategies
}

\author{
Sara Li-Chou Han, Claudia E. Henninger, Phoebe Apeagyei \& David Tyler
}

\begin{abstract}
This chapter investigates the current techniques employed by upcycled and sustainable fashion brands to communicate the features and benefits of their products, as well as their benefits to consumers and society at large. At the same time we look at the effectiveness of these strategies in the modern fashion industry. An interpretivist methodology was utilised in this chapter, with 14 in-depth semi-structure interviews providing the basis for the findings and discussion section. Interviewees were selected purposively and include nine ethical fashion brands, and five sustainable fashion experts (CSR specialist, artist and mending activist, upcycled and sustainable fashion expert, and closed loop production experts). Findings included key industry perspectives on communication and consumer issues relating to sustainability, design and behaviour change. Insights about knowledge brands and designers believe consumers already hold, how this informs design and production decisions, and what issues brands and designers are still querying in consumer behaviour are presented. Information on the current strategies employed to communicate in-store and through multi-channel media, the effectiveness of these techniques and what brands and designers still want and need to know regarding these communication strategies are also covered.
\end{abstract}

\section{Keywords: Fashion, Upcycling, Sustainability, Communication, Circular Economy, Closed-Loop Production.}

\section{Introduction}

On a daily average a consumer is exposed to over 3,500 marketing messages, of which only a small number of actual adverts and products/services can be recalled without prompting (Gibson 2005). This has various implications: first, a majority of messages are lost and do not reach the intended audience. Second, there is an information overflow, which makes it challenging to design an advert that has an impact in terms of being recalled. Third, consumers will only notice messages that are relevant to them. Thus, in order to increase the odds of product and brand recall and overcome challenges faced with information overload, fashion companies seek to broadcast their core values through a variety of channels; such as flickering 
billboards, web pop-ups, social media messages, in-store communication, magazine adverts, Aboards, and garment labels. In order to communicate their message, retailers need to identify, measure, and understand their market, and target a specific segment within it with a unique offering, which provides features and benefits to that group not available elsewhere (Webb 2007). Messages communicated are ideally short, creative, and distributed through a variety of channels, in order to stand out from competitive brand advertising. Moreover, a majority of fashion marketing communicating is visual or non-verbal, and thereby easily identified (Solomon and Rabolt 2004), however, campaigns must also be underpinned by research in order to establish the goals for an effective promotional strategy (Lea-Greenwood 2013).

After one of the worst garment factory accidents in the history of the fashion industry at Rana Plaza in Bangladesh, in which thousands lost their lives (Parveen 2014) - aspects of social and environmental sustainability have regained centre-stage. A new wave of sustainability concern has emerged that re-emphasises key issues from the 1990s, namely worker rights and safety, conditions in factories, and, in more generally, labour laws. Sustainability in itself is a fuzzy concept that lacks a clear-cut definition, yet it is intuitively understood (Markusen 2003; Gunder 2006). Sustainability within this chapter follows in line with the Triple Bottom Line (TBL) (Elkington 2004) and encompasses social, environmental, and economic aspects. The social aspect includes, but is not limited to providing workers with safe working conditions and fair wages, as well as a focus on improvements that can be made in order to strengthen a society, in terms of investments in public facilities, such as outdoor spaces, schools, and community centres (Harris 2003). Environmental sustainability links to utilising less harmful raw materials and the reuse or recycling of materials. Economic sustainability relates to preventing any imbalance that could damage or destroy the agricultural and/or industrial production within a country. In order to be fair and 'sustainable' the production process must produce the goods/services on a continuous basis and be financially viable for stakeholders at every level (Harris 2003).

The fashion industry has seen a dramatic change in its industry landscape, with increasing numbers of fashion companies incorporating sustainability practices throughout their daily business routines and in their supply chain at large (e.g. Henninger et al. 2015; Hendriksz 2016). These practices include the use of organic materials, the re-use and recycling of materials through upcycling processes, acquisition of eco-labels, and looking after employee welfare. Current lexicon in the industry distinguishes between two types of fashion production: slow- and fast-fashion. The latter facilitates hyper consumption and mass-production and 
continuously fosters a fashion appetite by producing new collections every two weeks (Sharma and Hall 2010). By contrast, slow-fashion takes a different philosophical stance in that it centres on sustainability values, reflected in the use of environmentally friendly raw materials and production techniques, consideration of workers' rights and safety; as well as a slowing down of the production life-cycle to produce a new fashion line either biannually or every quarter (Fletcher 2008; LeBlanc 2012). The emerging fashion collections have been described as eco-, green-, ethical-, or sustainable fashion, with each of these terms being used interchangeably to describe the same phenomenon (Brown 2011; Dickson et al. 2011). To explain, Fletcher (2008) associates sustainable fashion with strong and nurturing relationships between consumers and producers, in which garments encourage versatility, inventiveness, personalisation and individual participation. Eifler and Diekamp (2013) echo this sentiment, characterising sustainable fashion by slow trends with long-lasting value and compelling design. This change in the business routine and overall supply chain is actively promoted in the companies' messages and incorporated as an integral part of their communication strategies. In its most basic form communication theory states that the organisation (source) is encoding a message and forwards it to a transmitter, before being picked up by the receiver (audience/stakeholders), who then decode the message to make sense of it (Fill 2009). Social and environmental sustainability cues can indicate to the consumer that the company is producing garments that are less negatively impactful on the environment compared to mainstream fashion offerings.

The ulterior motive of sustainability communication is to alter the course of current consumption patterns, moving away from the insatiable consumer fashion appetite (Sharma and Hall 2010), which puts unreasonable pressure on manufacturers to cut corners and overlook worker safety. Instead conscientious, sustainable fashion consumption is promoted, with regard to all actors in the supply chain. The Nordic Initiative defined sustainable fashion consumption as the use of clothing for purposes beyond utilitarian needs, including 'identity making'; achieved without jeopardising the ability of future generations to meet their needs (Eder-Hansen et al. 2012). This definition and understanding of sustainable consumption links with the Brundtland Commissions' understanding of sustainable development (World Commission on Environment and Development 1987), which is a key priority for governments and other non-governmental organisations; the UK being no exception to this.

Sustainable fashion consumption is outlined as a sub-set of the sustainable fashion system. Consumer attitude and behaviour change that leads to reductions in the negative TBL impacts from buying, wearing, using, maintaining, and eventually disposing of fashion goods is 
emphasised. Demanding sustainable alternatives, caring for garments in less impact intensive ways and the responsible disposal or recycling of obsolete goods are also key practices (EderHansen et al. 2012). Extant research (e.g. Gam et al. 2010) highlights that consumers are more likely to buy products made by companies with an environmentally friendly business ethos, and that those who were environmentally conscious a price premium. However, environmentally friendly products were successful only if customers perceived the regular product attributes as superior to competitors' conventional offerings. Research indicates that consumers still actively seek out cheap fashion alternatives, as price is a major determinant when it comes to making a purchase decision (Joergens 2006; Pookulangara and Shephard 2013). Similarly, Goworek et al. (2012) suggest that there is an 'values-action' gap between consumers stating that they want to purchase green alternatives and actually translating their intentions into purchasing behaviour. In order for consumers to be able to make an informed decision, especially when purchasing sustainable fashion, information needs to be broadcasted to the audience in a clear and coherent manner. Yet, past studies have pointed out that the information provided predominately focuses on environmental aspects of sustainability (e.g. Sheth et al. 2010; HaBrookshire and Norum 2011). Potential conflicting messages portrayed across different media lead to confusion and consumer scepticism (e.g. Gam and Banning 2011), and negative consequences overall.

Extant research (e.g. Han et al. 2015) has focused on consumer perceptions of sustainable fashion and remarked that sustainable fashion was perceived to consist of basic, unremarkable styles or of out-dated, 'hippie' fashions, yet consumers indicated that they would be inclined to purchase upcycled garments if the styles were relevant to them. Consumer perceptions within the context of sustainable fashion have been widely researched, yet current research lacks to understand how organisations that are producing sustainable fashion not only communicate their message to their audience, but also analyse how their consumers perceive their messages. This research addresses this gap by investigating how sustainable fashion brands understand their consumers' perceptions of sustainable fashion. 


\section{Methodology}

This research utilises a qualitative research approach to investigate what the current techniques employed by upcycled and sustainable fashion brands are to communicate the ethos behind their products and the benefits to consumers and society. Fourteen in-depth semi-structured interviews form the basis of this research. Informants were selected from nine ethical fashion brands with experience of designing, producing or retailing upcycled or ethical fashion, and five sustainable fashion experts. Purposive sampling procedures selected informants to represent the range of market levels and expertise present in the fashion industry. Brands and designers ranged from higher profile labels that show regularly on and off schedule at London Fashion week, to medium-sized enterprises with their own bricks and mortar premises, smaller labels and start-ups, producing limited collections for loyal customer bases, mainly reached through social media. Ethical fashion experts were selected based on their specialist knowledge and experience of the industry and their distinct and varied perspectives, to give a broad range of viewpoints from the most forward thinking areas. Table 1 provides an overview of participants.

\section{Table 1: Study Participants}

\begin{tabular}{|l|l|}
\hline Brand 1 & $\begin{array}{l}\text { A well-established Berlin based business that displayed and retailed upcycled fashion } \\
\text { and jewellery from all over Europe and provided a network hub for the local } \\
\text { sustainable design community. }\end{array}$ \\
\hline Brand 2 & $\begin{array}{l}\text { A micro sized ethical cycle wear enterprise based in London. The owner and director } \\
\text { of this brand had previously held roles designing collections for two different London } \\
\text { based upcycled fashion brands. }\end{array}$ \\
\hline Brand 3 & $\begin{array}{l}\text { A London upcycled fashion label of a UK based charity raising money for vulnerable } \\
\text { children in Romania. Both the head designer and creative director were interviewed. }\end{array}$ \\
\hline Brand 4 & $\begin{array}{l}\text { A well-established organic clothing line from London, produced under ethical } \\
\text { conditions in China and printed in the UK. The brand specialised in printed organic } \\
\text { cotton and hemp t-shirts. }\end{array}$ \\
\hline Brand 5 & $\begin{array}{l}\text { A high profile upcycled fashion brand based in Spain and the UK, with production in } \\
\text { Bulgaria. The brand also functions as a consultant and facilitator for outsourced ethical } \\
\text { and upcycled production in Bulgaria. }\end{array}$ \\
\hline Brand 6 & $\begin{array}{l}\text { A collaborative studio shop in London that is used to design, showcase and sell } \\
\text { sustainable and ethical fashion and accessories, focusing on high quality handmade }\end{array}$ \\
\hline
\end{tabular}


craftsmanship, fair trade, and transparency of production.

A well-established micro-enterprise upcycling brand based in Bristol with a background

Brand 7 in academic research informing sourcing decisions. This brand manufactured and produced through a network of local UK makers and artisans.

A high profile upcycling brand, known for campaigning and public engagement, and

Brand 8 pioneering collaborations between educational institutions and upcycling innovators. Based in London with production in Italy.

A London based charity which raised money to fund international development

Brand 9 projects to improve working conditions in the global textile industry. The charity operates an award winning in-house upcycling label.

Expert 1 had a background in sustainable business practice in the fashion industry,

\section{Expert 1} having devised an implemented the first corporate social responsibility strategy for a major UK based online retailer. Now based in New York and working as an independent advisor.

\section{Expert 2 had a background in fashion design and academia, and was currently}

\section{Expert 2} working as an artist and mending activist, having founded organisations to map mending practice and devise a critical agenda for mending research. Now based in Cuba.

Expert 3 was an ethical fashion educator and writer, with a background in design and

Expert 3 academia, having published several well received books on sustainable design practice. Now based in New York and pursuing further research into artisanal craft skills.

\section{Experts 4 and 5 were a researcher and a founding executive from a closed-loop}

Experts 4 production company based in London, researching and developing a technique to and 5 enable end-of-use clothes and textiles to be processed back into new yarn, textiles and clothing.

Semi-structured interviews were conducted with brands and designers on how they currently communicated their ethos to their consumers, what information is important to know about consumers, and areas in which they felt more understanding was needed. Interview schedules provided a flexible guide to the order and flow of questioning for each interview. A mixture of different kinds of questions allowed to explore the way interviewees understood issues related 
to the research topics, whilst still being flexible in following alternative areas of enquiry during the course of the interviews (Bryman 2012). Interviews with sustainable fashion experts covered topics pertaining to each informant's area of expertise, such as corporate social responsibility in the mainstream fashion industry, consumer understanding, media and communication, design and closed-loop production. In flexible semi-structured interviewing style, questions varied between respondents to reflect what data could most appropriately be collected from each specific informant and how interviewees were directing the flow and emphasis of the data gathering. Thematic analysis allowed key themes to emerge from the data, broken down into single units of analysis, such as a sentence or phrase. From these indicators, concepts could then be generated to build theories (Bryman 2012).

\section{Results}

Presented in this section are the findings from key sustainable fashion industry informants. Perspectives on what the brands and designers believed consumers already knew, and the implications of this for design and production issues were highlighted. Areas in which brands and designers felt more clarity was needed were also covered.

\section{Consumers}

Table 2. Key Theme: Consumers

\begin{tabular}{|l|l|l|l|}
\hline Sub-theme & Summary & Illustrative Quote & Informant Cited \\
\hline $\begin{array}{l}\text { Consumers } \\
\text { own } \\
\text { knowledge }\end{array}$ & $\begin{array}{l}\text { Consumers are unwilling } \\
\text { to or unaware of how to } \\
\text { change }\end{array}$ & $\begin{array}{l}\text { "...this consumer focused industry } \\
\text { creates cognitive dissonance..." }\end{array}$ & Expert 1 \\
\hline $\begin{array}{l}\text { What it is } \\
\text { important to } \\
\text { know about } \\
\text { consumers }\end{array}$ & $\begin{array}{l}\text { Design and price come } \\
\text { first. Ethics are a bonus. }\end{array}$ & $\begin{array}{l}\text { "What they really want is just to know } \\
\text { that everything is OK without them }\end{array}$ & Brand 2 \\
\hline $\begin{array}{l}\text { having to do anything to find that out." } \\
\text { Consumers } \\
\text { don't care }\end{array}$ & $\begin{array}{l}\text { Design and price can } \\
\text { convert consumers to } \\
\text { sustainable purchases }\end{array}$ & $\begin{array}{l}\text { "...you've got people that don't really } \\
\text { care, and they are buying it for design } \\
\text { and price." }\end{array}$ & Brand 5 \\
\hline
\end{tabular}




\begin{tabular}{|c|c|c|c|}
\hline $\begin{array}{l}\text { Knowing what } \\
\text { consumers } \\
\text { want }\end{array}$ & $\begin{array}{l}\text { What would appeal to } \\
\text { consumers in these } \\
\text { markets in terms of } \\
\text { wants, needs and } \\
\text { preferences }\end{array}$ & $\begin{array}{l}\text { "It's whether they like the product at the } \\
\text { end of the day. And are they willing to } \\
\text { part with their hard earned cash for it?" }\end{array}$ & Brand 6 \\
\hline $\begin{array}{l}\text { Knowing what } \\
\text { consumers } \\
\text { will spend }\end{array}$ & $\begin{array}{l}\text { What price ranges } \\
\text { consumers are looking } \\
\text { for }\end{array}$ & $\begin{array}{l}\text { "I think our garments are priced } \\
\text { comparatively to the high street. Our } \\
\text { price point goes from } £ 30 \text { to } £ 100 \text { / } \\
£ 120 \text {..." }\end{array}$ & Brand 7 \\
\hline $\begin{array}{l}\text { How to design } \\
\text { for consumers }\end{array}$ & $\begin{array}{l}\text { How products are } \\
\text { designed and how they } \\
\text { look was the most } \\
\text { effective way of } \\
\text { appealing to consumers. }\end{array}$ & $\begin{array}{l}\text { "You've just got to make a really great } \\
\text { product. It's got to be what people want." }\end{array}$ & Brand 2 \\
\hline $\begin{array}{l}\text { Uniqueness of } \\
\text { designs }\end{array}$ & $\begin{array}{l}\text { The one of a kind } \\
\text { exclusivity of upcycled } \\
\text { designs was appealing } \\
\text { for consumers. }\end{array}$ & $\begin{array}{l}\text { "People like the fact that is it limited } \\
\text { edition, which is inherently connected to } \\
\text { the fact that it is upcycled." }\end{array}$ & Brand 7 \\
\hline $\begin{array}{l}\text { Do they buy } \\
\text { for quality? }\end{array}$ & $\begin{array}{l}\text { How do consumers view } \\
\text { the quality of fast } \\
\text { fashion? }\end{array}$ & $\begin{array}{l}\text { "That would be very interesting, to know } \\
\text { people's opinions towards fast fashion } \\
\text { and quality." }\end{array}$ & Brand 5 \\
\hline $\begin{array}{l}\text { Do they buy } \\
\text { for function or } \\
\text { need? }\end{array}$ & $\begin{array}{l}\text { Do consumers seek } \\
\text { functionality and high } \\
\text { performance from their } \\
\text { clothing? }\end{array}$ & $\begin{array}{l}\text { "I am interested in whether people want } \\
\text { things to perform that well." }\end{array}$ & Brand 2 \\
\hline $\begin{array}{l}\text { Social status } \\
\text { and stigma }\end{array}$ & $\begin{array}{l}\text { Social stigma still exists } \\
\text { towards second hand } \\
\text { clothing }\end{array}$ & $\begin{array}{l}\text { "But then a lot of people don't like buying } \\
\text { second-hand clothes because they think } \\
\text { it's dirty. They just don't like it." }\end{array}$ & Brand 5 \\
\hline $\begin{array}{l}\text { Do they care } \\
\text { about ethics? }\end{array}$ & $\begin{array}{l}\text { Do consumers care } \\
\text { about the ethics of how } \\
\text { their clothes were } \\
\text { made? }\end{array}$ & $\begin{array}{l}\text { "The consumer that is not interested in } \\
\text { who makes your clothes or ethical } \\
\text { issues is a very difficult consumer to } \\
\text { sway." }\end{array}$ & Brand 8 \\
\hline
\end{tabular}




\begin{tabular}{|l|l|l|l|}
\hline $\begin{array}{l}\text { The values- } \\
\text { action gap }\end{array}$ & $\begin{array}{l}\text { How to convert } \\
\text { customers who } \\
\text { expressed sustainable } \\
\text { consumption intentions } \\
\text { into actual sales }\end{array}$ & $\begin{array}{l}\text { "What do we need to close that gap? Is } \\
\text { it better marketing? Is it better }\end{array}$ & \\
& advertising? Is it better sex appeal? Is it & Expert 1 & \\
& & & \\
\end{tabular}

Informants expressed the opinions that consumers were, on the whole, unwilling to acknowledge or unaware of how their consumption behaviour contributed to wider problems caused by the fashion industry. The idea of cognitive dissonance, in which individuals experience discomfort when holding two conflicting beliefs (Sun and Guo 2013) was discussed in relation to continued consumption in the face of growing ethical awareness. When asked about what is important to know about consumers, the consensus from key informants was that design and price were the most important factors for consumers. Knowing what they were willing to spend and what sort of designs and styles they were looking for, as well as other aspects of their lifestyles, which could identify their preferences were vital. Informants were of the view that ethics were unimportant for most consumers and would only be viewed as a secondary benefit. In order to make sustainable fashion desirable for consumers, it was felt that the right designs had to be offered at competitive prices. Unique designs and limited edition supply created by upcycling can also create an appealing exclusivity for consumers.

Questions were raised by informants on what extra qualities consumers were seeking in garments, such as high quality, longevity, functionality, and ethics, and if any of these things were important to consumers. The idea of social status from designer brands and labels was also discussed, as well as the inverse of the social stigma attached to buying second-hand clothes. This presents a challenge for designers creating garments from post-consumer textiles, as a negative connotation may be attached to these materials. A challenge is presented in how to best communicate the desirable qualities of such garments to consumers. A further challenge is also presented to sustainable fashion designers when attempting to convert expressed sustainable consumption intentions into actual sales. As highlighted by Goworek et al. (2012), various studies have shown that consumers who profess to hold ethical views often do not transfer their intentions into ethical purchase behaviour, thus forming a 'values-action gap'. In both these instances, understanding current strategies used by designers and brands in presenting information, and how consumers receive this information is key to the success of promoting sustainable fashion consumption. 


\section{Communication}

\begin{tabular}{|c|c|c|c|}
\hline \multicolumn{4}{|c|}{ Table 3. Key Theme: Communication } \\
\hline Sub-theme & Summary & Illustrative Quote & Informant Cited \\
\hline $\begin{array}{l}\text { In-store } \\
\text { dialogue }\end{array}$ & $\begin{array}{l}\text { Knowledgeable brand owners on } \\
\text { hand to advise and share the stories } \\
\text { of the products that appeals to their } \\
\text { customers. }\end{array}$ & $\begin{array}{l}\text { "So I think for us it's just } \\
\text { having a shop. We just } \\
\text { start getting direct } \\
\text { feedback. We know } \\
\text { customers like and what } \\
\text { they don't like." }\end{array}$ & Brand 6 \\
\hline $\begin{array}{l}\text { Social media, } \\
\text { PR and press }\end{array}$ & $\begin{array}{l}\text { Social media was cited as the main } \\
\text { method communication with } \\
\text { consumers }\end{array}$ & $\begin{array}{l}\text { "Obviously since social } \\
\text { media has come along it } \\
\text { has been a lot easier to } \\
\text { kind of gauge who your } \\
\text { audience are and directly } \\
\text { market to them." }\end{array}$ & Brand 4 \\
\hline $\begin{array}{l}\text { Big brands } \\
\text { using social } \\
\text { media }\end{array}$ & $\begin{array}{l}\text { For large multi-national brands, } \\
\text { customers are providing market } \\
\text { information and asking questions. }\end{array}$ & $\begin{array}{l}\text { "Quite often it seems to } \\
\text { be coming from the } \\
\text { feedback mechanisms } \\
\text { they have on their social } \\
\text { media, through their blog, } \\
\text { through their website." }\end{array}$ & Brand 7 \\
\hline $\begin{array}{l}\text { Communicating } \\
\text { upcycling to } \\
\text { consumers }\end{array}$ & $\begin{array}{l}\text { Appealing to consumers through the } \\
\text { design and style rather than the } \\
\text { ethics was the most successful } \\
\text { approach. }\end{array}$ & $\begin{array}{l}\text { "Then the best is to start } \\
\text { from the design side and } \\
\text { show how cool the design } \\
\text { is. And how you can use } \\
\text { materials that were } \\
\text { already used." }\end{array}$ & Brand 1 \\
\hline $\begin{array}{l}\text { Story and } \\
\text { emotional link }\end{array}$ & $\begin{array}{l}\text { Consumers found human stories } \\
\text { about workers easier to connect with } \\
\text { than more abstract ideas about } \\
\text { climate change and environmental } \\
\text { degradation. }\end{array}$ & $\begin{array}{l}\text { "I think people are more } \\
\text { interested in knowing } \\
\text { who has made it, where } \\
\text { the fabric came from, if it } \\
\text { had a story." }\end{array}$ & Brand 2 \\
\hline
\end{tabular}




\begin{tabular}{|c|c|c|c|}
\hline $\begin{array}{l}\text { Market } \\
\text { research }\end{array}$ & $\begin{array}{l}\text { Talking to their current market was } \\
\text { their main form of market research. }\end{array}$ & $\begin{array}{l}\text { "We always try and work } \\
\text { out who they actually are } \\
\text { and why they are } \\
\text { motivated to buy." }\end{array}$ & Brand 7 \\
\hline $\begin{array}{l}\text { Media and } \\
\text { communication }\end{array}$ & $\begin{array}{l}\text { Although the mainstream press has } \\
\text { been covering the issue, it was still } \\
\text { falling short. }\end{array}$ & $\begin{array}{l}\text { "I think we need a lot } \\
\text { more kind of support from } \\
\text { media in general... to } \\
\text { help people understand } \\
\text { what they can do, what } \\
\text { they should be doing, and } \\
\text { why." }\end{array}$ & Expert 1 \\
\hline $\begin{array}{l}\text { Integrating into } \\
\text { the mainstream }\end{array}$ & $\begin{array}{l}\text { Ethical fashion needs to be } \\
\text { integrated instead of being treated as } \\
\text { a novelty. }\end{array}$ & $\begin{array}{l}\text { "You just don't get a } \\
\text { Goodone piece put } \\
\text { alongside a Chanel jacket } \\
\text { in deep summer in Elle } \\
\text { magazine. It doesn't } \\
\text { happen, it's still so } \\
\text { segregated." }\end{array}$ & Brand 7 \\
\hline
\end{tabular}

Informants outlined current sustainable fashion communication strategies for brands and designers, including in-store dialogue, social media content, public relations agencies, and editorial. In-store dialogues for brands with their own premises presented a chance to connect with consumers and share stories of how items had been produced. This provides a unique shopping experience and enables brands to equip consumers with information about the fashion industry in an engaging and non-confrontational manner. It also provides an opportunity to gauge consumer reactions to new products, services, price points and information provided, offering vital feedback for these businesses.

Social media was perhaps the most commonly used strategy to connect with a wider audience. Sharing related content and stories allowed brands to communicate their ethos and non-product related posts. These posts also communicate a lifestyle, ethos, and experiences to an audience, which has already shown an initial interest sustainability issues. Social media was mentioned time and again by the key informants as their main communication strategy, allowing brands to collect feedback and market research, and to tell the story of their company by openly 
associating with issues and causes they found important, and other brands and designers, which they supported. By more easily gauging audiences through social media, directed marketing strategies could be put in place by the brands to offer consumers the most appropriate products. Social media also affords brands the opportunity to respond expressly to questions from customers in an open forum.

In communicating upcycled fashion to the public and emphasising its appeal, informants tended towards an opinion that establishing qualities of design and style before ethics would be a more successful strategy in engaging consumers. Once desirable fashion aesthetics had been achieved, it would then be possible to inform consumers about sustainable credentials, provenance, and garment care practices. Using language and terms, which consumers easily understand and can engage with was seen as vital, as for some consumers, psychological barriers to accepting second-hand textiles may exist. In creating engaging information around sustainable fashion, it was also felt that consumers found emotional stories concerning those working in the fashion industry easier to connect with rather than more abstract ideas about climate change and environmental degradation. The latter are seen as intangible aspects that are hard to grasp and make sense of and may not affect everyone in the same manner.

To find out more about their present and potential customers, current forms of market research ranged from social media and in-store feedback to expressions of regret at a lack of market research or complete disconnection from the marketing side of their business altogether. For the majority of key informants, talking and connecting with their customers was their main form of market research, although there was a recognised need to appeal to a wider audience than just those who were engaged with issues of sustainability. For some brands it was not explicitly clear how to go about this, and a certain measure of scepticism was expressed once again regarding the 'values-action gap'. Queries were raised about how to close the gap between expressed intentions and actual purchasing behaviour.

Informants also felt that efforts from the mainstream media and fashion press to cover sustainable fashion were disappointing. On the one hand the media have covered stories about working conditions and labour rights abuses in Asia, but on the other hand, responsible alternatives to consuming products made by the companies creating injustice were not shown in any meaningful way. It was felt that sustainable alternatives were often shown as a novelty and not integrated into mainstream media and fashion as equal and viable options to the current offerings and methods of consumption. 


\section{Analysis and Discussion}

In many ways, what is true for standard and mainstream fashion (fast-fashion) is also true for sustainable and circular economy fashion (slow-fashion). For effective communication, messages should be under-pinned by relevant research to identify the intended audience and most effective forms of transmission. Short, creative messages, delivered through a wide variety of media, often using highly engaging visual or non-verbal forms target the predetermined audience (e.g. Solomon and Rabolt 2004). In mainstream and value fashion, promotional messages encourage hyper-consumption through a high turnover of new product lines. For sustainable and circular economy fashion, a paradoxical challenge arises in conveying a message, which aims to reduce consumption impacts and change consumer behaviour, yet also sell more products at the right price for the target market (Black 2011). Circular economy fashion communication aims to nurture relationships between consumers and producers and encourage responsible consumption choices which make use of products designed with longlasting value and enduring style (Fletcher 2008; Cooper et al. 2013). Personal creativity is emphasised, in which non-purchase related lifestyle choices offer greater versatility, inventiveness and personalisation through practices such as mending, customising and swapping (Busch 2008). Information about company supply chains, ethics, and sustainability ethos must be communicated in a clear and coherent manner as an integral part of each brands' communication strategy, in a way which connects and is relevant to consumers. It is in this departure of intended outcomes where mainstream strategies and those of the circular economy begin to deviate. Circular economy fashion brands operate less impactfully than their mainstream rivals, and must combine this message with a compelling presentation of welldesigned and desirable products. We found eight key elements that can be summarised in the circular economy fashion communication canvas (Figure 1): 


\section{THE CIRCULAR ECONOMY FASHION COMMUNICATION CANVAS}

\begin{tabular}{|c|c|c|c|}
\hline RELEVANT & TARGET & & MULTI \\
\hline RESEARCH & AUDIENCE & MESSAGE & CHANNEL \\
\hline $\begin{array}{l}\text { E.g. industry trends, } \\
\text { competitor analysis, } \\
\text { current issues in } \\
\text { industry, market } \\
\text { research }\end{array}$ & $\begin{array}{l}\text { Clear consumer profile } \\
\text { (e.g. age, occupation, } \\
\text { income, interests) }\end{array}$ & $\begin{array}{l}\text { E.g. what is the brand } \\
\text { ethos? Key values? Key } \\
\text { attributes? }\end{array}$ & $\begin{array}{l}\text { Reaching a wide } \\
\text { audience by combining } \\
\text { online and offline } \\
\text { channels }\end{array}$ \\
\hline COHERENT & VISUALLY & COMPELLING & FEEDBACK \\
\hline VALUES & ENGAGING & PRODUCTS & LOOPS \\
\hline $\begin{array}{l}\text { Core values must be } \\
\text { clearly communicated } \\
\text { and followed through } \\
\text { across the supply chain }\end{array}$ & $\begin{array}{l}\text { Use of creative, short, } \\
\text { unique text, images and } \\
\text { symbols }\end{array}$ & $\begin{array}{l}\text { Unique pieces that } \\
\text { attract consumers to } \\
\text { buy into the slow- } \\
\text { fashion movement }\end{array}$ & $\begin{array}{l}\text { Creating feedback } \\
\text { loops, which incorporate } \\
\text { suggestions from } \\
\text { stakeholders across the } \\
\text { supply chain }\end{array}$ \\
\hline
\end{tabular}

\section{Figure 1: The Circular Economy Fashion Communication Canvas}

The brands and designers interviewed had taken the stance of offering more conscientious choices to responsible fashion consumers. Products offered were designed for lasting style and versatility, incorporating socially and environmentally aware materials and production. Although extensive research had often been carried out in how to source reused, recycled or secondary and sustainable raw materials, not all brands carried through the message of the full extent of their sourcing efforts into their communications strategy. Sustainability ethos was often highlighted by brand websites; however style and design preferences and correct pricing were noted as being the most important points to be aware of when communicating with consumers, which the relevant research into consumer opinion, lifestyle and behaviour would reveal. Informants also highlighted further queries regarding consumers for which appropriate research was still necessary; such as whether consumers were interested in quality, functionality or ethics, and how it would be possible to close the 'values-action gap' and convert expressed good intentions into sustainable behaviour. 
In order to communicate their company ethos and the features and benefits of their products to consumers, informants outlined two main strategies of social media content and in-store dialogue. In identifying a target audience, the advantages of social media lay in enabling brands direct access to individuals with a prior expression of interest in sustainability issues. In-store dialogue also enabled brands to target individuals who were actively engaged in sustainable consumption by their visit to specific sustainable fashion shops; however a clear idea of the target audience for sustainable fashion or circular economy fashion was not readily available to the informants. Brands involved with academic research were able to take advantage of the collaborative opportunities to gather more information about their target audience, creating open and effective communication and assisting positive developments into the industry as a whole.

Messages communicated through social media enabled brands to re-post non-fashion related sustainability content which aligned closely with their company ethos, demonstrating a clear message about their beliefs and values, and reaching out to a wider audience. Barriers to communicating this message beyond the internet and social media were the lack of coverage from the mainstream media and mainstream fashion. Inadequate exposure and a lack of integration of sustainable alternatives left many brands unable to connect with a mainstream fashion audience. Despite growing consumer awareness, the fashion industry shows a marked reluctance towards transparency. Leadership and support from larger well-established brands in the industry was felt to be vital to instigate any sort of change.

As well as websites, blogs, social media and in-store dialogue, some brands had experience of utilising PR agencies and placing editorial in fashion publications, enabling a multichannel communication approach; however, full utilisation of this approach was limited by the micro and small sizes of each enterprise. Increased availability of information online has resulted in individuals being more informed than in the past, and it is through these channels of online and social engagement that consumers seem most ready to receive these messages. Using social comparison and peer to peer dialogue may also provide a platform to engage individuals through more positive messages of social change and clean technologies than in guilt inducing judgements of previous behaviour, as well as offering fresh opportunities for individuals to make the right decisions going forward.

A coherent message about company values was often demonstrated through each brands' website, and through online articles by sustainable fashion bloggers. Information on the provenance of materials and production was given, highlighting the ethos behind each brand's 
activities in creating enduring and sustainable fashion. For a fully functioning circular fashion system to be in place, understanding of the entire lifecycle by all participants is required, including consumers. This can only be achieved through a clear and coherent communication of values; demonstrating the best alternatives and responsible choices to consumers, rather than pointing out what they were currently doing wrong. Informants felt that feelings of guilt would not be helpful in changing consumer attitudes. Converting the way individuals think about consumption is balanced very finely between communicating the right message and going too far, making individuals feel judged and guilty for their consumption behaviour. Research by Zane et al. (2015) has shown that consumers who wilfully ignore ethical product attributes often denigrate other, more ethical consumers who seek out and use this information in making purchase decisions; but that denigration becomes less strong if the wilfully ignorant consumers have a second opportunity to act ethically after initially ignoring the ethical product information.

Brands and designers interviewed created design led, fashion forward garments, modelled in styled images and product shots. Each brand had a distinctive style, logo and graphic design approach. These elements all worked together to create a visually engaging identity, often presented through a strong online presence; however many informants felt that mainstream media coverage was lacking in provision. Informants were often frustrated that sustainable fashion was often shown as a novelty and not integrated alongside other fashion editorial. Not enough was being done to highlight responsible alternatives to continued fashion consumption or to show sustainable style as being equally desirable as high street fashion. Informants were unanimous in their opinion that style and design were the most effective ways to appeal to consumers, who would only regard ethics as a bonus addition. Connecting with consumers through aesthetics was vitally important in order to create a platform on which to engage individuals on the sustainable credentials and human stories regarding garment workers and the fashion industry.

The distinctive style of each brand resulted in design led fashion pieces and highly compelling products, however the extra work in sourcing materials and smaller production runs ensuring ethical standards often led to higher prices. Successfully communicating the wider global benefits of producing in this way to consumers was key to generating sales of products and services for circular economy brands. The strongest results reported in gaining this level of understanding and acceptance, including sales and repeat custom, were again through online interactions and in-store dialogue in dedicated ethical fashion stores. Providing enough 
information about the ethical product credentials and origin of the source materials needed to be carefully balanced against showing garments for their aesthetic appeal.

Once again, social media and in-store dialogue also presented opportunities for feedback from consumers, allowing individuals to express opinions and reactions towards new products, production information and the presentation of the message communicated. Feedback can also take the form of product returns and take back schemes, in which the opportunity to identify product failures or asses life-cycle impacts is presented. Retail feedback from wholesale customers is also key to developing and growing circular economy fashion, and integrating collections into a wider variety of outlets. Limited understanding from UK based retail buyers regarding the variability of upcycled stock and fears of inconsistency and poor quality have also presented barriers to wider acceptance. Identifying the most effective retail strategy for sustainable fashion has been an on-going challenge to the industry. Barriers include sourcing solely from one stream, such as post-consumer textiles. Brands utilising a variety of sources such as pre- and post-consumer textiles, recycled textiles and sustainably sourced fabrics have shown more success in scaling up their operations for wholesale supply. A constant process of open dialogue and feedback between suppliers, designers, producers, makers, retail buyers, consumers, users and those dealing with the use-phase and end-of-life stages is vital to share information essential to the development of a successful circular economy fashion industry.

\section{Conclusions}

Current understanding by sustainable and circular economy fashion brands points towards a communication strategy built around emphasising the design, style and aesthetics of products, without leaning too heavily on the provenance and ethical credentials of supply chains, or holding in mind clear target audience. Products must certainly be compelling and design led to compete with the mainstream, however the under-pinning consumer research and strategic considerations must also be included in business activities to ensure effective communication of a brands ethos, values and message in a way with connects with the target audience. It is clear that circular economy fashion communication strategies would benefit from further research into how to identify target consumers, and profile current patrons, in order to determine strategies to close the 'values-action gap'. Small and micro enterprises are often limited in their resources to carry out vital research which would under-pin all business and communication activities; however collaborations with academic research partners with shared sustainability goals offer greater scope for developing the pool of knowledge available. Key areas for further inquiry 
include identifying the target audience, their wants, needs and lifestyle preferences, including how best to communicate with these individuals, and how to integrate sustainable fashion into the mainstream media and garment industry to reach a wider market and make best practice more commonplace. 


\section{References}

Black, S. (2011). Eco-chic: The Fashion Paradox. London: Black Dog Publishing.

Brown, S. (2011). Future Factory: Sass Brown is coming to NTU. Future Factory (online). [online]. Available from: http://futurefactory.weebly.com/live-event-streams.html [Accessed March 20, 2012].

Bryman, A. (2012). Social Research Methods. 4th ed. Oxford: Oxford University Press.

Busch, O. von. (2008). FASHION-able: Hacktivism and Engaged Fashion Design. University of Gothenburg.

Cooper, T. et al. (2013). Design for Longevity: Guidance on increasing the active life of clothing.

Dickson, M., Cataldi, C. and Grover, C. (2011). The Slow Fashion Movement. Not Just a Label, pp.1-6. [online]. Available from: https://www.notjustalabel.com/editorial/slow-fashionmovement [Accessed July 20, 2016].

Eder-Hansen, J. et al. (2012). The NICE consumer research summary and discussion paper.

Eifler, C. and Diekamp, K. (2013). Consumer Acceptance of Sustainable Fashion in Germany. Research Journal of Textile and Apparel, 17(1).

Elkington, J. (2004). Enter the Triple Bottom Line. In J. Henriques, A., \& Richardson, ed. The Triple Bottom Line: Does it all Add Up?. London: Earthscan.

Fill, C. (2009). Marketing Communications: Interactivity, Communities and Content. 5th ed. Harlow, UK: Prentice Hall.

Fletcher, K. (2008). Sustainable Fashion and Textiles: Design Journeys. London: Earthscan. Gam, H.J. et al. (2010). Quest for the eco-apparel market: a study of mothers' willingness to purchase organic cotton clothing for their children. International Journal of Consumer Studies, 34(6), pp.648-656.

Gam, H.J. and Banning, J. (2011). Addressing Sustainable Apparel Design Challenges With Problem-Based Learning. Clothing and Textiles Research Journal, 29(3), pp.202-215.

Gibson, O. (2005). Shopper's Eye View of Ads That Pass Us By. The Guardian, pp.3-5. [online]. Available from:

http://www.theguardian.com/media/2005/nov/19/advertising.marketingandpr [Accessed June 11, 2016].

Goworek, H. et al. (2012). The sustainable clothing market: an evaluation of potential strategies for UK retailers. International Journal of Retail \& Distribution Management, 40(12), 
pp.935-955.

Gunder, M. (2006). Sustainability: Planning's Saving Grace or Road to Perdition? Journal of Planning Education and Research, 26, pp.208-221.

Ha-Brookshire, J. and Norum, P. (2011). Cotton and sustainability. International Journal of Sustainability in Higher Education, 12(4), pp.369-380.

Han, S.L.-C., Tyler, D. and Apeagyei, P.R. (2015). Upcycling as a design strategy for product lifetime optimisation and societal change. In Conference Proceedings - Product Lifetimes And The Environment.

Harris, J.M. (2003). Sustainability and sustainable development. International Society for Ecological Economics. [online]. Available from: http://isecoeco.org/pdf/susdev.pdf [Accessed July 15, 2013].

Hendriksz, V. (2016). 55 fashion companies sign 'milestone' sustainability covenant. Fashion United, pp.1-20. [online]. Available from: https://fashionunited.uk/news/fashion/55-fashioncompanies-sign-milestone-sustainability-covenant/2016070420984 [Accessed June 11, 2016].

Henninger, C.E. et al. (2015). Sustainable Supply Chain Management in the Slow-Fashion Industry. In Sustainable fashion supply chain management: from sourcing to retailing. London: Springer, pp. 129-154.

Joergens, C. (2006). Ethical fashion: myth or future trend? Journal of Fashion Marketing and Management, 10(3), pp.360-371.

Lea-Greenwood, G. (2013). Fashion Marketing Communications. Chichester: John Wiley \& Sons.

LeBlanc, S. (2012). Sustainable Fashion Design: Oxymoron No More?

Markusen, A. (2003). Fuzzy Concepts, Scanty Evidence, Policy Distance: The Case for Rigour and Policy Relevance in Critical Regional Studies. Regional Studies, 37(6-7), pp.701-717.

Parveen, S. (2014). Rana Plaza factory collapse survivors struggle one year on. BBC News. [online]. Available from: http://www.bbc.co.uk/news/world-asia-27107860.

Pookulangara, S. and Shephard, A. (2013). Slow fashion movement: Understanding consumer perceptions-An exploratory study. Journal of Retailing and Consumer Services, 20(2), pp.200-206.

Sharma, T.. and Hall, C. (2010). Green PLM for fashion \& apparel - White Paper. Infosys. [online]. Available from: http://www.infosys.com/industries/retail/white- 
papers/Documents/green-plm-fashion-apparel.pdf [Accessed February 1, 2012].

Sheth, J.N., Sethia, N.K. and Srinivas, S. (2010). Mindful consumption: a customer-centric approach to sustainability. Journal of the Academy of Marketing Science, 39(1), pp.21-39. Solomon, M.R. and Rabolt, N.J. (2004). Consumer Behaviour in Fashion. 2nd ed. New Jersey: Pearson Education Ltd.

Sun, Y.-S. and Guo, S. (2013). Media Use, Social Comparison, Cognitive Dissonance and Peer Pressure as Antecedents of Fashion Involvement. Intercultural Communication Studies, 1, pp.117-139.

Webb, B. (2007). Retail brand marketing in the fashion industry. In T. Hines \& M. Bruce, eds. Fashion marketing: contemporary issues. Oxford: Elsevier, p. 324.

World Commission on Environment and Development. (1987). Our Common Future. Zane, D.M., Irwin, J.R. and Reczek, R.W. (2015). Do less ethical consumers denigrate more ethical consumers? The effect of wilful ignorance on judgments of others. Journal of Consumer Psychology. [online]. Available from: http://linkinghub.elsevier.com/retrieve/pii/S1057740815001011. 